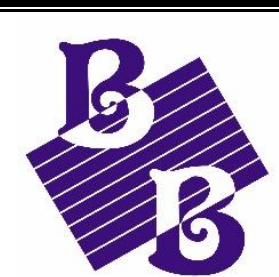

BioBacta

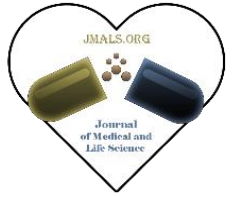

Journal of Medical and Life Science www.jmals. journals.ekb.eg

\title{
Quantification of DNA and AgNORs correlating to cyclin D1-immunoexpression in human breast cancer
}

\section{Mahmoud Assem Hamed ${ }^{1 *}$, Saeed Mahmoud Saeed Mohamed ${ }^{2}$ Eman Ahmed Youssef ${ }^{1}$, Radwa Mohammed Rashad ${ }^{3}$, and Mona Abdel-Hamed Yahia ${ }^{1}$}

${ }^{1}$ Department of Histochemistry and Cell Biology, Medical Research Institute, Alexandria University, Alexandria, Egypt.

${ }^{2}$ Department of Histopathology and Cytology, Faculty of Medical Laboratory Sciences, West Kordufan University, Kordufan, Sudan.

${ }^{3}$ Department of Pathology, Medical Research Institute, Alexandria University, Alexandria, Egypt.

Dr. Mahmoud Assem Hamed (* Corresponding author); Master of Science in Histochemistry and Cell Biology, Medical Research Institute, Alexandria University, Alexandria, Egypt. E-mail: assem.edu.eg@gmail.com Phone: 00201025589478. Postal address: 98 El-Fouad St, Sohag, Egypt, 82524.

Prof. Saeed Mahmoud Saeed Mohamed: Assistant Professor of Histopathology and Cytology, Faculty of Medical Laboratory Sciences, West Kordufan University, Kordufan, Sudan.

Prof. Eman Ahmed Youssef; Consultant of Histochemistry and Cell Biology, Medical Research Institute, Alexandria University, Alexandria, Egypt.

Prof. Radwa Mohammed Rashad; Assistant Professor of Pathology, Medical Research Institute, Alexandria University, Alexandria, Egypt.

Prof. Mona Abdel-Hamed Yahia; Professor of Histochemistry and Cell Biology, Medical Research Institute, Alexandria University, Alexandria, Egypt.

Received September 1, 2020; Accepted November 10, 2020; Published November 15, 2020

DOI: 10.21608/jmals.2020.123510

\section{Abstract:}

Background: Assessment of cell proliferation through the evaluation of cyclin D1, AgNORs, and DNA content provides a promising approach to the prognosis of breast cancer. Therefore, this work aimed to evaluate the prognostic significance of AgNORs and DNA image cytometry, and their relation to cyclin D1 immunoreactivity in breast cancer.

Subjects and methods: This study was carried out on 50 prospective biopsies taken from patients with breast tumors. They were divided into control (10 cases) and benign (10 cases) as well as malignant (30 cases) groups. Computer-assisted image analysis cytometry is applied to evaluate the count of positive reactions of AgNORs and 
cyclin D1, and an integrated optical density (IOD) technique is used to quantify DNA content in the tissues stained by Feulgen stain and to assess the density of cyclin D1 immunoreactivity.

Results: The comparison between the mean count of cyclin D1 positive reaction (Mean \pm SD: $31.10 \pm 26.39$ ) and AgNORs dots (Mean \pm SD: $4.64 \pm 2.77$ ) revealed a statistically significant difference $(\mathrm{P}<0.001)$ in the normal group and in the malignant group as well as in total cases. The association between the IOD parameter for Feulgen stain (Mean \pm SD: $77.35 \pm 27.99$ ) and cyclin D1 immunostaining (Mean \pm SD: $151.90 \pm 37.38$ ) showed a statistically significant difference throughout all of the individual groups $(\mathrm{P}<0.001)$.

Conclusions: These results indicate that image cytometry may be a valuable method for quantitating DNA, AgNORs, and cyclin D1-immunostaining, and that provides valuable information that may have prognostic significance for patients with breast cancer.

Keywords: DNA quantification; AgNORs; Cyclin D1; Image cytometry; Immunohistochemistry; Breast cancer.

\section{Introduction}

Breast cancer is considered a disease of Western women; over half (52\%) of new breast cancer cases and $62 \%$ of deaths occur in economically developing countries [1]. In Egypt, according to the National Population-Based Cancer Registry Program, breast cancer was the commonest site of cancers $(32.0 \%)$ among women in 2014 and by 2050 there will be a 3fold increase in cancer incidence relative to 2013 [2].

The assessment of cellular proliferation is a very critical and precise parameter used in biological and histopathological studies. There are many ways are used to assess cell proliferation which involve the immunohistochemical demonstration of cyclin D1, which regulate cell cycle-related antigens such as cyclin-dependent kinases (CDKs) [3], the histochemical method of silver stain to demonstrate the Nucleolar Organiser Regions (NORs), which are chromosomal segments containing loops of DNA in which ribosomal RNA is encoded [4], and the assessment of DNA content by using Feulgen stain, which is mainly concerned with DNA quantification in cell nuclei by image cytometry [5].

Therefore, the present study aimed to assess cell proliferation through histochemical and immunohistochemical studies, and evaluate the prognostic role of these markers in breast cancer and study the correlation between them.

Cyclin D1 is a product of (CCND1) gene, which is located on chromosome 11q13. Cyclins and CDKs are tightly responsible for the regulation and progression of the cell cycle [6]. Synthesis of Cyclin D1 is stimulated by growth factor signals, which form active complexes with CDK4/6 in early G1. The primary substrate of $\mathrm{CDK} 4 / 6$ is the retinoblastoma protein $(\mathrm{pRb})$, which binding and repressing the activity of the transcription factor E2F. The phosphorylation of $\mathrm{pRb}$ by the activated $\mathrm{CDK} 4 / 6$ disassociates $\mathrm{pRb}$ from $\mathrm{E} 2 \mathrm{~F}$, leading to transcription of several genes including E-type cyclins which are involved in the G1-to-S transition [7].

NORs are located in the cell nucleoli during interphase, containing non-histone proteins that bind silver ions and are selectively visualized by the silver staining method in routinely processed cytohistological samples [8]. Hence, it is referred to as these proteins as Argyrophilic Nucleolar Organizer Regions (AgNORs) [9]. Theoretically, the neoplastic cell population could show a defect in nucleolar aggregation, association, ploidy, or increased transcriptional activity, which demonstrates an increased AgNORs count [10]. As 
well as, it has been shown that AgNORs frequency within nuclei is significantly higher in malignant cells than in normal reactive, or benign neoplastic cells [11]. And so, their number per nucleus is correlated with the rate of ribosomal RNA transcription, cell proliferation, and DNA ploidy [12].

Feulgen found that when thymonucleic acid (now known as DNA) is mildly hydrolyzed to a purinic acid, the loss of purines exposes aldehyde groups. He termed his discovery the nuclear reaction since it is a reaction specific for aldehydes based on the formation of a magenta-colored compound when aldehydes react with fuchsin-sulfuric acid. The positive reaction occurs only in the presence of DNA, whereas yeast nucleic acid (RNA) did not give the same reaction. Since 1937, the Feulgen reaction is still in use as an effective staining technique in studies of chromosomes and genetic cytochemistry assays [13]. The extrapolation from biochemical studies of chromatin postulated that the localization of Feulgen dark and the light stain is represented relative to DNA densities so that the staining intensity is proportional to the DNA concentration [14].

\section{Subjects and Methods}

Tissue samples were obtained from patients diagnosed with breast tumors in the Department of Pathology, Medical Research Institute (MRI), Alexandria University, Egypt during the period from February to August 2015. Tissue specimens were obtained from 30 cases having IDC, and from 10 cases were diagnosed with benign breast lesions, in addition to 10 normal breast samples were taken from tissue adjacent to the tumors. The diagnosis of the specimens was made according to the World Health Organization (WHO) classification of the tumors. The malignant cases graded according to the Nottingham Prognostic Index (NPI) [15]. Samples from all studied cases were subjected to the following:

\section{Histopathological study:}

Tissues from all studied cases were fixed in neutral buffered formalin and processed. Paraffin sections, $4 \mu$ thick, were used for routinely staining with H\&E in Histochemistry and Cell Biology Department, MRI to examine the histopathological changes. Stained sections were reviewed by three pathologists.

\section{Histochemical Procedures:}

\subsection{Feulgen Staining [16]}

Sections were deparaffinized and rehydrated in descending series of alcohol then rinsed in distilled water. Slides were hydrolyzed by immersing in $1.0 \mathrm{~N} \mathrm{HC} 1$ at $60^{\circ} \mathrm{C}$ for 8 minutes, then the slides were rinsed in two changes of distilled water. After that, sections were placed in Schiff's reagent for 15-30 minutes at room temperature in a dark place. The slides were transferred directly for three changes in bisulfite water every 10-15 seconds. The slides were washed in running tap water for 2 minutes, and then the slides were counterstained with fast green (0.01 gm in $100 \mathrm{ml}$ 95\% alcohol). Finally, sections were dehydrated, cleared, and mounted. The control slide was untreated with HCL; notice the absence of magenta colour and presence of a green colour (negative reaction).

\subsection{AgNORs silver staining [16]}

Deparaffinized paraffin sections were rehydrated and washed in 3 changes of distilled water. A large drop of silver-working solution (50\% silver nitrate and $2 \%$ formic acid in gelatin with ratio 2:1) was put on each section in the slide. The slides were placed horizontally in the humidified staining covered container in a dark place and were incubated for 45 minutes. After that, the slides were washed in 5\% thiosulphate solution for 5 minutes. Then the slides were 
washed in running tap water. Finally, sections were dehydrated, cleared, and mounted. The control slide was processed as other slides after boiling in water, the results appeared as the homogeneous yellow colour, and the positive reaction of silver staining was dark brown dots.

\section{Immunohistochemical staining of cyclin D1:}

The immunohistochemical method was utilized to study the expression of cyclin D1 in paraffinembedded breast sections [17]. In brief, $5 \mu \mathrm{m}$ thick sections were prepared, deparaffinized using 2 changes of xylene, and rehydrated. The sections were submerged in antigen retrieval (citrate buffer saline $\mathrm{pH}$ 8.4) in an oven at $95^{\circ} \mathrm{C}$ for 20 minutes and then left at room temperature for 20 minutes to cool. The sections were treated with $3 \% \mathrm{H}_{2} \mathrm{O}_{2}$ in phosphate buffer saline (PBS), then incubated with serum blocking reagent for 30 minutes. The sections were incubated with the primary antibody of cyclin D1 (Genemed Biotechnologies company, South San Francisco, USA) at $4^{\circ} \mathrm{C}$ overnight. After incubation is done, the sections were treated with conjugated secondary antibody (ABC-HRP reagent) for 30 minutes, stained with diaminobenzidine (DAB), and counterstained with hematoxylin. For negative controls, the primary antibody was replaced with PBS. Each step was followed by PBS washing. Evaluation of cyclin D1immunohistochemical score was arbitrarily graded as negative, weak, moderate, and strong.

\section{Image analysis:}

The images of each slide of groups were captured using a numerical aperture of a high resolution of a 16bit digital camera (1280X1024 pixels). Images were viewed by $40 \mathrm{X}$ objective lens and recorded using Olympus light microscope - equipped with Spot digital camera and computer program MATLAB software (image $\mathrm{J}$ ) in Histochemistry and Cell Biology Department, MRI.

\subsection{Counting:}

4.1.1 AgNORs dots numbers were counted/ 100 cells through ten images collected under image analyzer by oil immersion magnification 100x objective lens (Bar $=20 \mu \mathrm{m})$.

4.1.2 The number of positive nuclei of cyclin D1 protein immunostaining was counted through ten images collected from ten fields for each case under image analyzer by $40 x$ objective lens $(\mathrm{Bar}=50 \mu \mathrm{m})$

\subsection{Integrated optical density (IOD):}

The measurement of the IOD changes of both histochemical stain (Feulgen stain) and immunohistochemical stain (cyclin D1) was carried out for the individual groups (normal, benign, and IDC). Maximum, minimum, and integrity of intense colour based on Gray-level acquisition and analysis of the data level were carried out by reading spot fixed areas of 10 images for each case. The IOD based on Graylevel transition probabilities in digitized images was graded from light to dark (0 up to 250) [18]. The average score across the whole image should be taken; IOD in digitized images was calibrated from strong to light (180 down to 70) by pixel. This calculation was proceeded after subtracting the pixel value from 250, the pick of lighter elimination.

\section{Statistical Analysis:}

Data were normally distributed according to the Kolmogorov-Smirnov (K-S) normality test and then analyzed using the statistical software package SPSS 20 by running a one-way ANOVA test. Followed by Post Hoc Test (Tukey) to measure the significance between groups, and a Paired t-test was used for comparing between Cyclin D1 and AgNORs/Feulgen stains. $\mathrm{P}$ values $\leq 0.05$ were considered statistically significant. 


\section{Results}

\section{Histopathological results:}

Photomicrographs of paraffin sections were taken under light microscopy and were been interpreted by the three pathologists. Normal breast tissue showed acini lined by epithelial cells resting on an intact myoepithelial cell layer figure (1A). The benign breast case, fibroadenoma, showed proliferating stromal elements compressing the ducts into slit-like space as seen in figure (1B). The malignant ductal epithelial cells of IDC GII have hyperchromatic or vesicular pleomorphic nuclei, acidophilic cytoplasm, and the intervening stroma is desmoplastic as seen in figure (1C). IDC GIII case showed a neoplastic growth formed of sheets of malignant ductal epithelial cells as seen in figure (1D).

\section{Histochemical results:}

\subsection{Feulgen Stain}

The staining reaction of Feulgen demonstrated DNA in the magenta colour of Schiff' reagent. Normal sections of breast tissue revealed strong DNA magenta colour in most epithelial cells of the breast ducts as in figure (1E), and marked colour intensity was seen in sections of benign, fibrocystic disease, the case as in figure (1F). Sections of malignant cases of both GII figure (1G) and GIII figure $(1 \mathrm{H})$ showed decreased DNA content represented by pale magenta colour comparing with normal and benign groups, negative nuclei appeared as green colour.

\subsection{AgNORs Stain}

The staining results, as seen by oil immersion magnifying (100x) under the light microscope, appeared as the homogenous pale brown colour represents negative stain, and dark brown dots of silver stain in the nuclei demonstrate positive reaction. The dark brown consists of small discrete inter-nuclear dots, and large structures resembling nucleoli (uniformly stain) or maybe aggregates of dots in the nuclear matrix. Normal breast tissue case showed (1.14) dotes in nucleoli as in figure (1I). A fibrocystic disease, benign, case showed an average number of dotes (2.19) in the nucleolus and nuclear matrix, presented in figure (1J). GII and GIII cases revealed an increased number of dotes (5.50 and 8.33 respectively) spread in the nuclear matrix as is shown in figure $(1 \mathrm{~K} \& \mathrm{~L})$.

\section{Immunohistochemical results of cyclin D1: Immunostaining positivity}

The immunohistochemical staining appeared as brown granules stained in the nuclei, and the blue colour indicated negative control nuclei. Normal breasts showed a negative expression of cyclin D1 in the ductal epithelial cells and rarely present in the myoepithelial ones as in figure $(1 \mathrm{M})$. Benign breast case revealed week nuclei expression of cyclin D1, presented by the figure $(1 \mathrm{~N})$. A strong positive expression of cyclin D1in invasive ductal epithelial cells and the stromal infiltrating cells was seen in GII and GIII as is demonstrated in figure (1O\&P). 


\section{Figure [1]}

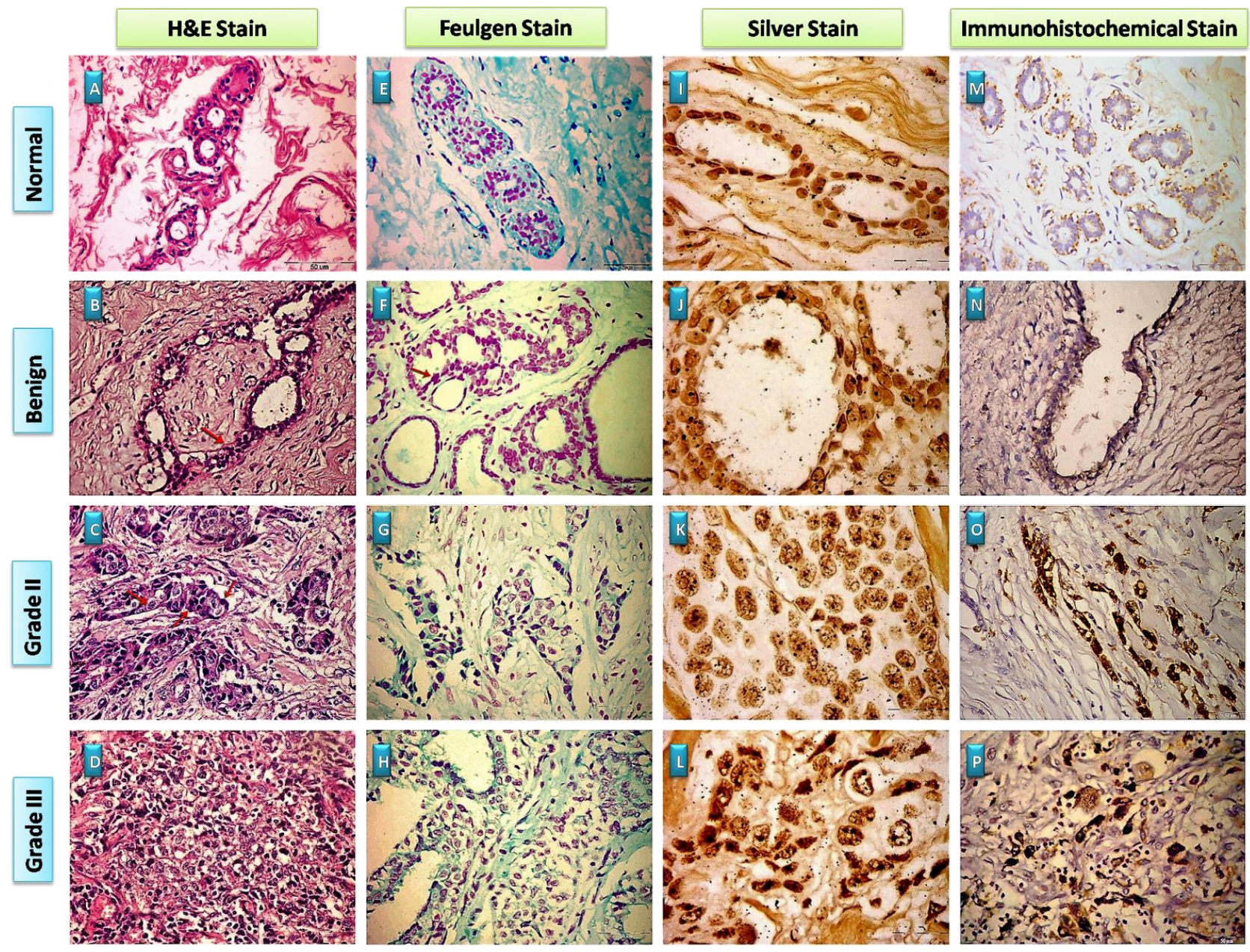

Figure [1]: Paraffin sections photomicrographs of breast tissue showing:

$[\mathrm{H} \& \mathrm{E}$ stain $-\mathrm{Bar}=50 \mu \mathrm{m}]$

(A) Normal case: the acini lined by epithelial cells resting on an intact myoepithelial cell layer, (B) Benign case: a fibroadenoma case showing proliferating stromal element compressing the ducts into slit-like space (arrow), (C) IDC GII case: the malignant ductal epithelial cells have hyperchromatic or vesicular pleomorphic nuclei (arrows) and acidophilic cytoplasm, (D) IDC GIII case: a neoplastic growth formed of sheets of malignant ductal epithelial cells.

[Feulgen stain - Bar $=50 \mu \mathrm{m}$ ]

(E) Normal case: an intense magenta colour of Feulgen stain in cuboidal ductal epithelial cells as well as in myoepithelial lining cells, (F) Benign case: a fibrocystic disease case showing marked magenta colour (arrow), (G) IDC GII case: a decreased DNA concentration appeared as pale magenta colour and negative green colour of epithelial ductal cells nuclei, (H) IDC GIII case: a decreased DNA content in invasive cells nuclei and negative green colour in nuclei of stroma tissue.

[Silver stain - Bar=20 $\mu \mathrm{m}$ ]

(I) Normal case: presented the least dark brown dotes of silver stain in nucleoli, (J) Benign case: a fibrocystic disease case show number of dark brown dotes $(2.19 \pm 0.36)$ in the nucleolus and nuclear matrix, (K) IDC GII case: an increased number of dark brown dotes $(5.50 \pm 0.71)$ spread in the nuclear matrix, (L) IDC GIII case: an increased number of dark brown dotes $(8.33 \pm 0.86)$ with huge size spread in vesiculated polymorphic nuclei.

[Immunostaining - Bar= $50 \mu \mathrm{m}$ ]

(M) Normal case: negative cyclin D1-immunostaining in the ductal epithelial cells and rarely present in the myoepithelial ones, the negative nuclei appeared as a blue colour, (N) Benign case: week nuclei expression of cyclin D1, (O) IDC GII case: a strong positive expression of Cyclin D1 in invasive ductal epithelial cells and stroma, (P) IDC GIII case: strong positive expression of cyclin D1 in the stromal infiltrating cells. 
Figure [2]
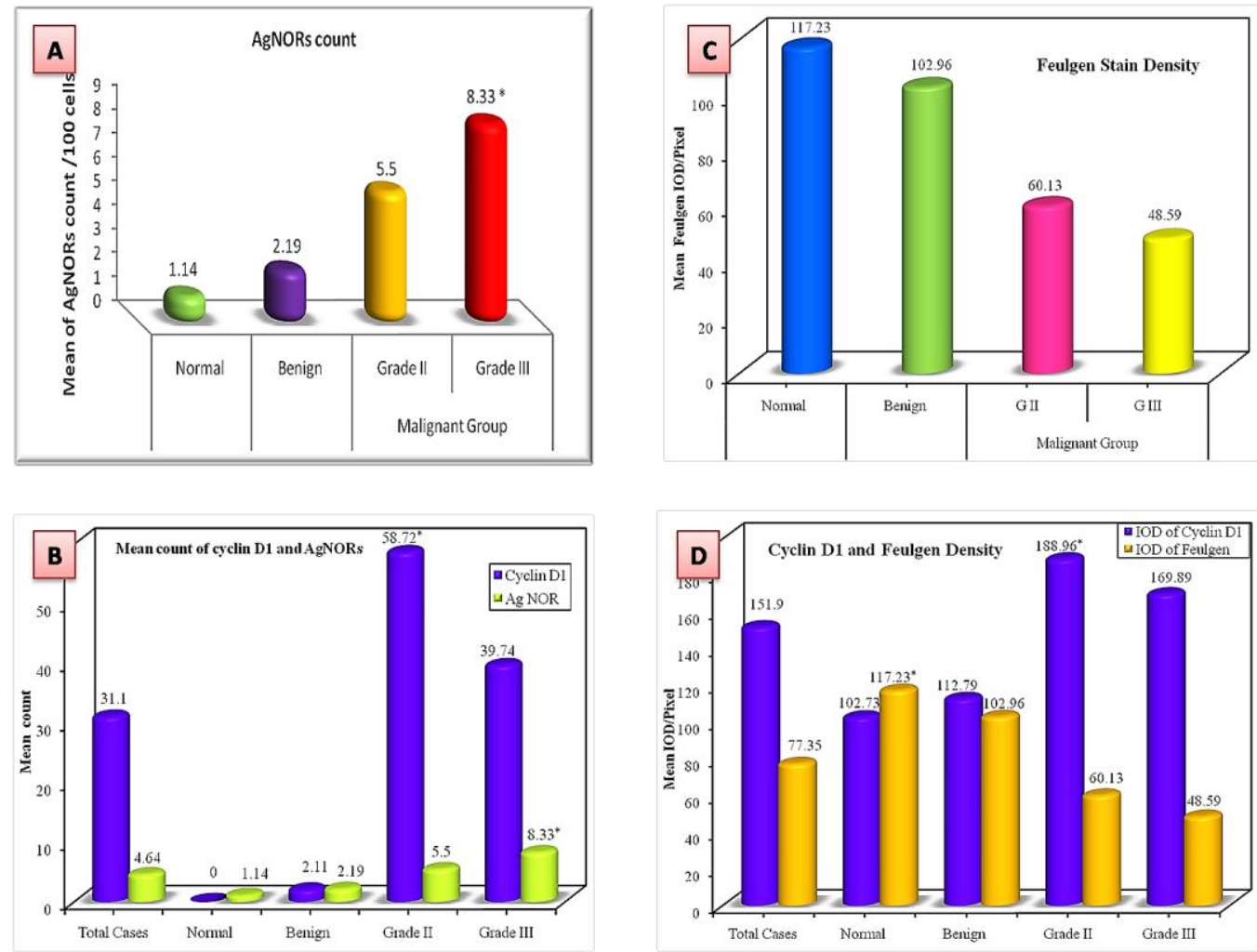

Figure [2]: (A) Bar graph illustrates the AgNORs (mean count) in individual groups. (B) Bar graph distributes the comparison between the mean count of cyclin D1 positive reaction and AgNORs dotes; there was a statistically significant difference between the mean count of both stains in the total cases, note: both stains count increase paralleled going from normal to malignancy. (C) The bar chart represents the mean Feulgen IOD /pixel in the individual groups. (D) The bar chart illustrates the comparison of the IOD mean value/pixel in both stainings of cyclinD1 and Feulgen; there was a significant difference of both stains in all individual groups, note: the low concentration of DNA parallel to high cyclin D1 expression.

\section{Image Cytometry}

\subsection{Counting:}

\subsubsection{AgNORs dots count / 100 cells result}

The mean values of AgNORs silver stain dots count for normal, benign, grade II, and grade III were $1.14 \pm$ $0.11,2.19 \pm 0.36,5.50 \pm 0.71$, and $8.33 \pm 0.86$ respectively. There was a statistically significant difference $(\mathrm{P} 1=0.003)$ was noticed between normal with each group, and there was a statistical difference
$(\mathrm{P} 2,3<0.001)$ was noticed between the rest of all individual groups as shown in table (1) and figure (2A).

\subsubsection{Comparison between Cyclin D1 scores and AgNORs count:}

At this comparison between the mean count of cyclin D1 positive nuclei/field and AgNORs dots/100 cells, we have seen that there was a statistically significant difference $(\mathrm{P}<0.001)$ between the mean count of cyclin D1 and AgNORs in the total cases. Separately, there was a statistically significant 
difference ( $\mathrm{P}<0.001)$ in the normal group as well as in the malignant group. Put there was no significant difference according to the benign group. These results are shown in table (2) and figure (2B).

\subsection{Integrated Optical Density (IOD) results:}

\subsubsection{IOD of Feulgen stain (histochemical stain)}

The mean value of IOD for the magenta colour illumination in individual groups ranged between (124.76 down to 43.65). There was a significant difference noticed in the malignant cases compared to normal ( $\mathrm{P}<0.001)$. Also, a significant difference was noticed in benign compared with the individual malignant groups $(\mathrm{P}<0.001)$ as well as the significant difference between GII and GIII $(\mathrm{P}<0.001)$. These results are illustrated in a table (3) and figure (2C).

\subsubsection{Comparison between Feulgen and cyclin D1 IOD}

The comparison between histochemical staining of Feulgen stain IOD and immunohistochemical staining of cyclin D1 stain IOD showed that there was a statistically significant difference between all of the individual groups $(\mathrm{P}<0.001)$. And that due to there was a decrease in the DNA amount in the groups forwarding from normal to malignancy as well as the increase in the colour intensity of cyclin D1 forwarding from normal to malignant groups. As shown in table (4) and figure (2D).

Table [1]: Comparison between the individual groups according to AgNORs dots count /100 cells:

\begin{tabular}{|c|c|c|c|c|c|c|}
\hline & \multirow{2}{*}{$\begin{array}{l}\text { Normal } \\
(n=10)\end{array}$} & \multirow{2}{*}{$\begin{array}{l}\text { Benign } \\
(n=10)\end{array}$} & \multicolumn{2}{|c|}{ Malignant } & \multirow[b]{2}{*}{$\mathbf{F}$} & \multirow[b]{2}{*}{$\mathbf{p}$} \\
\hline & & & $\begin{array}{l}\text { Grade II } \\
(\mathrm{n}=\mathbf{1 8})\end{array}$ & $\begin{array}{l}\text { Grade III } \\
\quad(n=12)\end{array}$ & & \\
\hline \multirow{3}{*}{$\begin{array}{l}\text { AgNORs } \\
\text { Min. - Max. } \\
\text { Mean } \pm \text { SD. }\end{array}$} & \multirow{3}{*}{$\begin{array}{c}1.0-1.30 \\
1.14 \pm 0.11\end{array}$} & \multirow{3}{*}{$\begin{array}{l}1.56-2.73 \\
2.19 \pm 0.36 \\
\end{array}$} & \multirow{3}{*}{$\begin{array}{l}4.55-6.65 \\
5.50 \pm 0.71\end{array}$} & \multirow{3}{*}{$\begin{array}{l}7.22-9.76 \\
8.33 \pm 0.86\end{array}$} & \multirow{3}{*}{$305.831^{*}$} & \multirow{3}{*}{$<0.001^{*}$} \\
\hline & & & & & & \\
\hline & & & & & & \\
\hline $\mathbf{p}_{1}$ & & $0.003^{*}$ & $<0.001^{*}$ & $<0.001^{*}$ & & \\
\hline $\mathbf{p}_{2}$ & & & $<0.001^{*}$ & $<0.001^{*}$ & & \\
\hline $\mathbf{p}_{3}$ & & & & $<0.001^{*}$ & & \\
\hline
\end{tabular}

F: F value for ANOVA tests, Sig. Bet. Groups. was done using the Post Hoc test (Tukey), $p_{1}$ : $p$-value for comparing between normal with each group, $\mathrm{p}_{2}$ : $\mathrm{p}$-value for comparing between benign with each of grades II and III, $\mathrm{p}_{3}$ : $\mathrm{p}$-value for comparing between grade II and III. *: Statistically significant at $\mathrm{p} \leq 0.05$. 
Table [2]: Distribution of mean count of cyclin D1 positive nuclei and AgNORs dotes

\begin{tabular}{|c|c|c|c|c|c|}
\hline & No. of cases & Cyclin D1 & Ag NOR & $\mathbf{t}$ & $\mathbf{p}$ \\
\hline \multicolumn{6}{|l|}{ Total Cases } \\
\hline Min. - Max. & & $0.0-85.10$ & $1.0-9.76$ & \multirow{2}{*}{$7.656^{*}$} & \multirow{2}{*}{$<0.001^{*}$} \\
\hline Mean \pm SD & & $31.10 \pm 26.39$ & $4.64 \pm 2.77$ & & \\
\hline \multicolumn{6}{|l|}{ Normal } \\
\hline Min. - Max. & $\mathrm{n}=10$ & $0.0-0.0$ & $1.0-1.30$ & \multirow{2}{*}{$33.292^{*}$} & \multirow{2}{*}{$<0.001^{*}$} \\
\hline Mean \pm SD & & $0.0 \pm 0.0$ & $1.14 \pm 0.11$ & & \\
\hline \multicolumn{6}{|l|}{ Benign } \\
\hline Min. - Max. & $\mathrm{n}=10$ & $1.20-3.0$ & $1.56-2.73$ & \multirow{2}{*}{0.328} & \multirow{2}{*}{0.750} \\
\hline Mean \pm SD & & $2.11 \pm 0.64$ & $2.19 \pm 0.36$ & & \\
\hline \multicolumn{6}{|l|}{ Grade II } \\
\hline Min. - Max. & $\mathrm{n}=18$ & $50.20-85.10$ & $4.55-6.65$ & \multirow{2}{*}{$29.204^{*}$} & \multirow{2}{*}{$<0.001^{*}$} \\
\hline Mean \pm SD & & $58.72 \pm 8.0$ & $5.50 \pm 0.71$ & & \\
\hline \multicolumn{6}{|l|}{ Grade III } \\
\hline Min. - Max. & $\mathrm{n}=12$ & $31.20-49.30$ & $7.22-9.76$ & \multirow{2}{*}{$18.324^{*}$} & \multirow{2}{*}{$<0.001^{*}$} \\
\hline Mean \pm SD & & $39.74 \pm 5.48$ & $8.33 \pm 0.86$ & & \\
\hline
\end{tabular}

$\mathrm{t}, \mathrm{p}$ : $\mathrm{t}$, the $\mathrm{p}$-value for Paired t-test for comparing between Cyclin D1 and AgNORs. *: Statistically significant at $\mathrm{p} \leq 0.05$.

Table [3]: Comparison between the four studies groups according to IOD of Feulgen

\begin{tabular}{|c|c|c|c|c|c|c|}
\hline \multirow[b]{2}{*}{ IOD of Feulgen } & \multirow{2}{*}{$\begin{array}{c}\text { Normal } \\
(n=10)\end{array}$} & \multirow{2}{*}{$\begin{array}{l}\text { Benign } \\
(n=10)\end{array}$} & \multicolumn{2}{|c|}{ Malignant Group } & \multirow[b]{2}{*}{$\mathbf{F}$} & \multirow[b]{2}{*}{$\mathbf{p}$} \\
\hline & & & $\begin{array}{c}\text { Grade II } \\
(\mathrm{n}=18)\end{array}$ & $\begin{array}{l}\text { Grade III } \\
\qquad(\mathrm{n}=12)\end{array}$ & & \\
\hline Min. - Max. & $107.66-124.76$ & $98.54-106.76$ & $53.98-64.90$ & $43.65-52.87$ & & \\
\hline Mean \pm SD & $117.23 \pm 6.15$ & $102.96 \pm 2.59$ & $60.13 \pm 3.04$ & $48.59 \pm 2.93$ & $855.953^{*}$ & $<0.001^{*}$ \\
\hline $\mathbf{p}_{1}$ & & $<0.001^{*}$ & $<0.001^{*}$ & $<0.001^{*}$ & & \\
\hline $\mathbf{p}_{2}$ & & & $<0.001^{*}$ & $<0.001^{*}$ & & \\
\hline $\mathbf{p}_{3}$ & & & \multicolumn{2}{|c|}{$<0.001^{*}$} & & \\
\hline
\end{tabular}

F: F value for ANOVA test, Sig. Bet. Groups were done using Post Hoc Test (Tukey). $\mathrm{p}_{1}$ : p-value for comparing between Normal and each other group. $\mathrm{p}_{2}$ : $\mathrm{p}$-value for comparing between Benign and each other group. $\mathrm{p}_{3}$ : $\mathrm{p}$-value for comparing between Grade II and Grade III. *: Statistically significant at $\mathrm{p} \leq 0.05$ 
Table [4]: Comparison of IOD between cyclin D1-immunostaining and Feulgen stain

\begin{tabular}{|c|c|c|c|c|c|}
\hline & No. of cases & IOD of Cyclin D1 & IOD of Feulgen & $\mathbf{t}$ & $\mathbf{p}$ \\
\hline \begin{tabular}{|l} 
Total Cases \\
Min. - Max. \\
Mean \pm SD
\end{tabular} & & $\begin{array}{c}100.11-195.54 \\
151.90 \pm 37.38\end{array}$ & $\begin{array}{c}43.65-124.76 \\
77.35 \pm 27.99\end{array}$ & $8.223^{*}$ & $<0.001^{*}$ \\
\hline \begin{tabular}{|l} 
Normal \\
Min. - Max. \\
Mean \pm SD.
\end{tabular} & $\mathrm{n}=10$ & $\begin{array}{c}100.11-106.0 \\
102.73 \pm 1.95\end{array}$ & $\begin{array}{c}107.66-124.76 \\
117.23 \pm 6.15\end{array}$ & $8.086^{*}$ & $<0.001^{*}$ \\
\hline \begin{tabular}{|l} 
Benign \\
Min. - Max. \\
Mean \pm SD
\end{tabular} & $\mathrm{n}=10$ & $\begin{array}{c}110.39-115.55 \\
112.79 \pm 1.86\end{array}$ & $\begin{array}{c}98.54-106.76 \\
102.96 \pm 2.59\end{array}$ & $9.329^{*}$ & $<0.001^{*}$ \\
\hline \begin{tabular}{|l} 
Grade II \\
Min. - Max. \\
Mean \pm SD
\end{tabular} & $\mathrm{n}=18$ & $\begin{array}{c}185.34-195.54 \\
188.96 \pm 2.78\end{array}$ & $\begin{array}{c}53.98-64.90 \\
60.13 \pm 3.04\end{array}$ & $127.192^{*}$ & $<0.001^{*}$ \\
\hline \begin{tabular}{|l} 
Grade III \\
Min. - Max. \\
Mean \pm SD
\end{tabular} & $\mathrm{n}=12$ & $\begin{array}{c}164.66-175.89 \\
169.89 \pm 4.07\end{array}$ & $\begin{array}{c}43.65-52.87 \\
48.59 \pm 2.93\end{array}$ & $92.164^{*}$ & $<0.001^{*}$ \\
\hline
\end{tabular}

$\mathrm{t}, \mathrm{p}: \mathrm{t}$, the p-value for Paired t-test for comparing between Cyclin D1 and Feulgen stain. *: Statistically significant at $\mathrm{p} \leq 0.05$.

\section{Discussion}

Neoplastic diseases have been defined as proliferative disorders characterized by uncoordinated cell growth, to reach a better understanding, it is of the utmost importance to have an in-depth knowledge of the mechanisms that control cell division [19]. Many ways were reported for direct or indirect assessment of cellular proliferation in many situations such as the use of antibodies, which became an important means of assessing cell proliferation. Several monoclonal antibodies react with different proliferating cell nuclear antigens and the proteins that regulate the cell cycle [3]. Also, the silver stained-NORs are a very useful tool in breast lesions [20]. As well as, DNA quantification in cell nuclei by image cytometry for tissues sections stained with Feulgen method, which is mainly concerned with DNA concentration [5]

Therefore, the present study aimed to assess cell proliferation through histochemical and immunohistochemical studies, and evaluate the prognostic role of these markers in breast cancer and study the correlation between them.

The present study showed that the cyclin Dl expression was predominantly, but not exclusively, nuclear staining, and tumor cells showed a considerable range of intensities within and between different sections in the individual groups. In some cases with strong nuclear staining, the cytoplasm was also stained, and mitotic figures were not stained. This result was agreed with several previous studies, who stated that 
cyclin D1 showed nuclear and cytoplasmic staining and had a substantial range of intensities between different sections [21, 22].

Besides, the present results for DNA image cytometry -IOD- of Feulgen histochemical stain showed a decreased significant difference noticed in the malignant cases compared with normal ( $\mathrm{P}<0.001$ ), and in benign compared with the individual malignant groups ( $\mathrm{P}<0.001)$ as well as the significant difference between the GII and GIII (P<0.001). Therefore, our results could reveal that DNA densities reflect the regional protein association of the DNA. As was illustrated in a previous study, the Feulgen dense regions may result from the aggregation of a specific class of histones by the alkaline buffer with consequent condensation of the DNA bound to the dark band of chromosomes. The Feulgen pale or negative regions may represent those in which non-aggregated proteins, histone, and non-histone. This was rendering that the DNA of those regions were subjected to diffusion or vulnerable to fragmentation in the Feulgen hydrolysis [14].

In agreement with the present results, another study reported that the staining intensity is proportional to the DNA concentration through the applications of the Feulgen reaction, which are concerned with DNA quantification in cell nuclei by image cytometry for ploidy evaluation in tumor pathology; these measurements are summarized to give the final IOD of the DNA concentration [23]. Therefore, these results revealed that DNA image cytometry for tissues stained with Feulgen stain could provide a good tool specified for DNA quantification. Following some investigators, who concluded that image analysis (IA) provides a valuable alternative method for assessing tumor cell proliferation, which could offer certain advantages over flow cytometry [24], especially, for genome quantification by DNA Densitometry [25].
Whereas, the comparison between DNA content identified by Feulgen stain and cyclin D1immunostaining, as regards to IOD, showed that there was an alternative statistically significant difference between all of the individual groups $(\mathrm{P}<0.001)$. This result could reveal that the cyclin D1 has evidence as a proliferative marker in malignant cells, which, probably, gives prognostic information for consideration of therapies.

Therefore, it may be suggested that the immunostaining evaluation using image analysis for counting and quantification of stain density (IOD) reflected the role of image analysis as a valuable method for assessing tumor cell proliferation. Confirming the present suggestion, Liu SC, et al. [26] reported that the scoring and image cytometry evaluation using immunohistochemistry of markers such as cyclin D1 could be used in many different studies as the variations of protein expression in tissue sections could yield prognostic information or could be useful in determining subtle effects of curative or prevention therapies.

As regards the silver stain (AgNORs), the results showed that the mean AgNORs count/100 cells in the benign group were $(2.19 \pm 0.36)$, and in the malignant group was $(6.92 \pm 0.79)$ with a statistically significant difference $(\mathrm{P}<0.001)$. This finding was following several studies, who stated that the differences in mean AgNORs count between carcinoma $(8.84 \pm 1.56)$ and that of benign breast lesions $(2.58 \pm 0.90)$ are highly significant $(\mathrm{P}=0.001)$ [27-29]. AgNORs count was significantly related to the histological grade [30]. Equally, there was a study suggested that the method may help discriminate benign from malignant disease or in distinguishing between low and high-grade malignancy [31]. This finding confirmed our results; there was a statistically significant difference ( $\mathrm{P}$ $<0.001$ ) of AgNORs dotes count between GII and GIII in invasive ductal carcinoma cases. 
The relation between AgNORs value and cancer prognosis was explained based on the biological function of the NORs. In vitro and in vivo studies have shown that the quantity of AgNORs is directly related to the ribosome biogenesis rate; the proliferating cells are tightly related to the length of the cell cycle; the shorter the cell cycle, the greater the synthesis of rRNA for each time unit. Therefore, AgNORs are presented in the nucleolus, so that the AgNORs value was thought to measure the rate of cell proliferation $[32,33]$. Thus, faster growth was suggested to explain the worse prognosis of cancers with high AgNORs values compared with cancer with low AgNORs values [34].

Furthermore, a highly significant association was found between AgNORs proteins quantity and tumor prognosis; AgNORs value showed independent prognostic value together with a ki67-labeling index, nodes state, and tumor size [35]. The numbers, the shape, and the distribution of AgNORs within the nucleus might be of potential use in predicting behavior in breast carcinomas [36].

Therefore, the current study revealed that the AgNORs count may be a better and more consistent indicator of changes in the proliferative capacity of breast tumors. This finding is in agreement with some investigators, who reported that the score number of AgNORs carried out in different tumor types demonstrated that malignant cells frequently present a greater AgNORs protein amount than corresponding non-malignant cells [37]. A high significant difference of AgNORs score $(p<0.05)$ was found in malignant with metastasis in comparison with those without metastasis [38]. They concluded that AgNORs stain is proven predictability may become a trustworthy milestone. Also, they revealed that the AgNORs staining technique is a relatively simple and rapid one, and can be applied to both aspiration smears and tissue sections. So that, our study proposed that AgNORs stain could be used as a good tool for assessing cell proliferation in the diagnosis and prognosis of breast cancer, especially, because it is simple, cheap, and available in any lab.

Moreover, our study revealed that there was a statistically significant difference $(\mathrm{P}<0.001)$ between the mean cyclin D1 score and AgNORs count in the normal and also the malignant groups. Put no significant difference $(\mathrm{P}<0.750)$ in the benign group. These results are in discrepancy with Mani CS, et al. 2015 [39] who concluded that there was no correlation between AgNORs with cyclin D1, and therefore, cyclin D1 action in hastening the G1/S phase transition did not impinge on the nucleolar size or number. Whereas AgNORs scores do not independently provide definite information concerning prognosis, it is proposed that they could contribute towards prognostication if considered in combination with specific clinicalmorphological parameters [40]. In this regard, our study may prove that cyclin D1 relates to good prognosis and AgNORs associate with poor prognosis for breast cancer.

\section{Conclusions}

The results which were presented in this work may prove that the evaluation of AgNORs and DNA content by image cytometry paralleled with cyclin D1immunoreactivity is may be considered as a good tool for assessment of the cell proliferation, and these markers may provide valuable prognostic information in breast cancer.

\section{Declarations}

Acknowledgments:

Prof. Dr. Hoda Mahmoud Khalifa; Professor of Histology and Cell Biology, Faculty of Medicine, Alexandria University has given helpful and valuable scientific support regarding the research revision.

\section{Funding:}


This research received no specific grant from any funding agency in the public, commercial, or not-forprofit sectors.

\section{Availability of data and materials:}

Not applicable.

\section{Authors' contributions:}

Yahia MAH conceived and designed the study.

Youssef EA and Rashad RM edited the manuscript.

Hamed MS and Mohamed SMS performed the experiments and wrote the paper. All authors read and approved the final manuscript

\section{Ethics approval and consent to participate:}

All cases were asked to freely volunteer to the study and informed written consents were gathered before their inclusion in the study according to the guidance of the Scientific Research Ethics Committee (IORG\#: IORG0008812).

\section{Consent for publication:}

All authors have read and agreed to the final version of the manuscript.

\section{Competing interests:}

No competing interests declared.

\section{References}

[1] Torre LA, Bray F, Siegel RL, Ferlay J, LortetTieulent J, Jemal A. Global cancer statistics, 2012. CA Cancer J Clin 2015; 65: 87-108.

[2] Ibrahim A S, Khaled $\mathrm{H} \mathrm{M}$, Mikhail $\mathrm{N} \mathrm{NH}$, Baraka H, and Kamel H. Cancer Incidence in Egypt: Results of the National Population-Based Cancer Registry Program. J Cancer Epidemiol 2014.

[3] Zaha DC. Significance of immunohistochemistry in breast cancer. World J Clin Oncol 2014; 5: 382-92.
[4] Sharma M, Manjari M, Kahlon SK. Proliferative indices, ki-67 immunostaining and nucleolar organizer region associated protein and their association with various grades of breast carcinomas. J Clin Diagn Res 2011; 5: 1371-74.

[5] Chieco P, Derenzini M. The feulgen reaction 75 years on. Histochem Cell Biol 1999; 111: 34558.

[6] Lodish H, Berk A, Zipursky SL, Matsudaira P, Baltimore D, Darnell J. Molecular Cell Biology. 4th ed. New York: Freeman; 2000. p. 222-46.

[7] Sjostrom J, Makela T. Apoptosis and the cell cycle in human disease. ELS 2006. https://doi: 10.1002/9780470015902.a0006043.

[8] Roy A, Bhatnagar S, Chatterjee M, Mandal G, Ghosh D. Quantitative DNA Assay (Ploidy), Koilocytotic Changes, and AgNOR Expression for Risk Estimation in Oral Leukoplakia. J Cancer Res Treat 2014; 2: 22-7.

[9] Omidi AA, Kalantari MR. Differentiation between prostatic carcinoma and nodular prostatic hyperplasia by AgNOR staining. Iran J Basic Med Sci 2001; 4: 62-70.

[10] Elemam IB, Elsheikh MA, Elnour AM, Abd Elhaleem HM, Alobaid AE. Assessment of proliferation activity by using nucleolar organiser regions count among Sudanese patients with prostate cancer and benign prostate hyperplasia. J Pharm Biomed Sci 2015; 5: 86366.

[11] Derenzini M, Ceccarelli C, Santini D, Taffurelli M, Trere D. The prognostic value of the AgNOR parameter in human breast cancer depends on the 
pRb and p53 status. J Clin Pathol 2004; 57: 75561.

[12] Costa AL, Araujo NS, Pinto Jr DS, Araujo VC. PCNA/AgNOR and $\mathrm{Ki}$ 67/AgNOR double staining in oral squamous cell carcinoma. J Oral Pathol Med 1999; 28: 438-4.

[13] Kasten FH. Robert feulgen and his histochemical reaction for DNA. Biotech Histochem 2003; 78: 45-9.

[14] Rodman TC, Tahiliani S. The Feulgen banded karyotype of the mouse: analysis of the mechanisms of banding. Chromosoma 1973; 42: $37-56$

[15] D'Eredita G, Giardina C, Martellotta M, Natale T, Ferrarese F. Prognostic factors in breast cancer: the predictive value of the Nottingham Prognostic Index in patients with a long-term follow-up that were treated in a single institution. Eur J Cancer 2001; 37: 591-6.

[16] Kiernan JA. Histological and histochemical methods: theory and practice. 3rd ed. London, New York, New Delhi: Arnold Publisher; 2001. p. 606.

[17] Peurala E, Koivunen P, Maria HK, Bloigu R, Vuorinen AJ. The prognostic significance and value of Cyclin D1, CDK4, and p16 in human breast cancer. Breast Cancer Res 2013. https://doi:10.1186/bcr3376.

[18] Matos LL, Stabenow E, Tavares MR, Ferraz AR, Capelozzi VL, Pinhal MA. Immunohistochemistry quantification by a digital computer-assisted method compared to semiquantitative analysis. Clinics 2006; 61: 41724.

[19] Cardo CC. Mutation of cell cycle regulators biological and clinical implications for human neoplasia. Am J Pathol 1995: 545-60.

[20] Bhatt J, Patel T, Sarvaiya S, Modha D, Gajjar M. Silver stained nucleolar organizer region count (AgNOR count)-a very useful tool in breast lesions. Natl J Med Res 2013; 3: 280-2.

[21] Bartkova J, Lukas J, Strauss M, Bartek J. Cyclin D1 oncoprotein aberrantly accumulates in malignancies of diverse histogenesis. Oncogene 1995; 10: 775-78.

[22] Gillett C, Fanti V, Fisher C, Bartek J, Dickson C, Barnes D, et al. Amplification and overexpression of cyclin D1 in breast cancer detected by immunohistochemical staining. Cancer Res 1994; 54: 1812-17.

[23] Biesterfeld S, Beckers S, Del Carmen M, Cadenas V, Schramm M. Feulgen Staining Remains the Gold Standard for Precise DNA Image Cytometry. Anticancer Res 2011; 31: 538.

[24] Dawson AE, Norton JA, David S, Weinberg DS. Comparative Assessment of Proliferation and DNA Content in Breast Carcinoma by Image Analysis and Flow Cytometry. Am J Pathol 1990; 136: 1115-24.

[25] Hardie CD, Gregory TR, Hebert PN. From Pixels to Picograms: A beginners' guide to genome quantification by feulgen image analysis densitometry. J Histochem Cytochem 2002; 50: 735-49. 
[26] Liu SC, Zhang SY, Babb JS, Ridge JA, KleinSzanto AJ. Image cytometry of cyclin D1: a prognostic marker for head and neck squamous cell carcinomas. Cancer Epidemiol Biomarkers Prev 2001; 10: 455-9.

[27] Jumaa AS, Altoraihi KM, Alabbasi DS. Role of AgNOR in Benign and Malignant Breast Lesions. Med J Babylon 2011: 149-56.

[28] Kumar A, Kushwaha AK, Kumar M, Gupta S. Argyrophylic nuclealar organizer region: their value and correlation with clinical prognostic factors in breast carcinoma. J Surg oncol 1997; 65: 201-4.

[29] Bankflavi A, Ofner D, Schmitz KJ, Krech R, Bocker W. Standardized in situ AgNOR analysis in breast pathology: diagnostic and cell kinetic implications. Pathol Res Prec 1999; 195: 219-29.

[30] Supramanian S, Shariff S, Andradi C. AgNORs and their relationship to cell size, histological grade, lymph node involvement, metastases and survival pattern in carcinoma of the breast : a study from south India. J Surg Oncol 1996; 62: 139-43.

[31] Egan M, Raafat F, Crocker J, Smith K. Nucleolar organizer regions in fibrous proliferations of childhood and infantile fibrosarcoma. J Clin Pathol 1988; 41: 31-3.

[32] Derenzini M, Trerè D, Pession A, Montanaro L, Sirri V, Ochs RL. Nucleolar function and size in cancer cells. Am J Pathol 1998; 152: 1291-7.
[33] Derenzini M, Trerè D, Pession A, Govoni M, Sirri V, Chieco P. Nucleolar size indicates the rapidity of cell proliferation in cancer tissues. $\mathbf{J}$ Pathol 2000; 191: 181-6.

[34] Derenzini M. The AgNORs. Micron 2000; 31: $117-20$.

[35] Ceccarelli C, Trere D, Santini D, Taffurelli M, Shieco P, Derenzini M. AgNORs in breast tumors. Micron 2000; 31: 143-49.

[36] Ahmed HG, Al-Adhraei MA, Ashankyty IM. Association between AgNORs and immunohistochemical expression of ER, PR, HER2/neu, and p53 in breast carcinoma. Pathol Res Int 2011. https://doi: 10.4061/2011/237217.

[37] Pich A, Chiusa L, Margaria E. Prognostic relevance of AgNORs in tumor pathology. Micron 2000; 31: 133-41.

[38] Bhatt J, Patel T, Sarvaiya S, Modha D, Gajjar M. Silver stained nucleolar organizer region count (AgNOR count)-very useful tool in breast lesions. Natl J Med Res 2013; 3: 280-2.

[39] Mani CS, Chander V, Kurian A, Annapurneshwari, Mahalingam S, Vimala R. Immunohistochemical analysis on the functional role of nucleolar enlargement in breast cancer. Int J Latest Res Sci Tech 2015: 39-45.

[40] Howell WM. Selective staining of nucleolus organizer regions (NORs). In: Busch $\mathrm{H}$, RothblumL, editors. The cell nucleus, New York: Academic; 1982. p. 89-143. 